\title{
DIMENSIONS AND STRATEGIES FOR ONLINE SUCCESS: VOICES FROM EXPERIENCED EDUCATORS
}

\author{
Lynne Schrum, Ph.D. \\ University of Georgia \\ Department of Instructional Technology \\ 604 Aderhold Hall \\ Athens, GA 30602-7144 \\ Telephone: 706-542-3810 \\ Fax: 706-542-4032 (fax) \\ Email: 1schrum@coe.uga.edu \\ http://it.coe.uga.edu/ 1schrum
}

Sunjoo Hong, Graduate Student

University of Georgia Department of Instructional Technology

Email: sunjhong@coe.uga.edu

http://www.arches.uga.edu/ sjhong/

\begin{abstract}
Online learning has become a popular method of education. Faculty members may know little about how to assist students in succeeding in a new learning environment, and students may be ill-prepared to tackle the new demands put upon them. Therefore, this research seeks to identify dimensions of successful online learners by examining primary screening documents and then mapping them to the literature base. Next, experienced online educators are asked to review the dimensions and to provide strategies that they use to ensure student success. Seven dimensions are identified and confirmed as significant, each dimension with slightly different importance - including access to tools; technology experience; learning preferences; study habits and skills; goals or purposes; lifestyle factors; and personal traits and characteristics. In addition, several online teaching strategies (including students' posting biographies; frequent interaction; collaboration; requiring participation; question-asking forums; topical flexibility; and minimizing technology requirements) have been recommended.
\end{abstract}

\section{KEY WORDS}

Learning effectivness, Distance education, Course planning, Faculty perspectives

\section{INTRODUCTION}

Learners throughout the world are demanding educational opportunities in an "anytime and anywhere" format, and institutions are responding by devoting substantial resources to develop online distance learning. Online learning has thus rapidly become a popular method of education for traditional and nontraditional students. Estimates are that by 2001 "more than $75 \%$ of traditional US colleges and universities will use distance-learning technologies and techniques in one or more 'traditional' academic 
programs" [1]. Faculty members are under enormous pressure to join this transition and put their courses online. However, this is not a simple endeavor; and the challenge is to understand the relationships between the user and the technology, the instructor and the participants, and the relationships among the participants [2], [3], [4]. Faculty members may have technical or pedagogical support in making this transition in their teaching; however, they may know little about how to assist students in succeeding in a new learning environment.

To provide information to assist faculty members to work with students in understanding the demands of online learning, as well as to better design effective online learning environments, this research seeks to identify the dimensions that characterize successful online learners. Next, the research gathers information from experienced online educators in order to validate these dimensions and investigate the strategies they have employed to support and insure success for all their students.

\section{REVIEW OF THE LITERATURE}

Recent developments in technology and access have offered organizations and universities the opportunity to improve traditional passive distance learning environments through increased communication, interactivity among participants, and incorporation of collaborative pedagogical models, specifically through electronic networks and groupware [5], [6], [4]. In this transformed model of distance learning, learners expect interactivity and close to "traditional" classroom based education. The demand for online courses, enhanced by the ease of access, media attention, and interest from the private sector, has accelerated the rush toward online learning activities. Some of the courses are traditional subject matter courses, often undergraduate, while others are geared more toward ongoing professional work activity. These include informal courses, professional development tutorials, and even full degree programs. Much uncertainty exists, however, about the conditions that are essential to create a successful venture for both educators and learners.

A growing body of literature has begun to emerge about the nature of learning online. Development of any educational environment is a complex task, but faculty members have had an especially difficult time changing the ways in which they teach in this milieu, regardless of these educators' own personal use of electronic media [7]. Faculty members must develop and design their activities and interactions in new ways, and they may be frustrated without the ability to recognize when students are puzzled [8]. Specifically, the traditional hierarchy is flattened, and the power and control are redistributed [9]. Kember urged designers to work toward deep learning, which requires moving away from excessive assignments, shallow assessments, and lack of freedom in activities [10]. These challenges go far beyond the need to be comfortable with the reliance on technology to support their courses [11].

Wiesenberg and Hutton identified three major challenges for the designer to consider: increasing time for delivery of the course (they estimate two or three times what is necessary for a traditional course), creating a sense of online community, and encouraging students to become independent learners [12]. They also reported fewer interactions than expected from participants of an online course.

These issues all have implications for faculty members and for students in an online environment. Quality assurance in these programs can be determined through outcome based evaluation, student feedback, appropriate technological and pedagogical support, and reviews by specialists (external and internal) of both the program and the instruction material [13].

Many educators work toward development of a virtual learning community, to move the experience beyond that of a collection of web based activities. Rogers used Wenger's theory of legitimate peripheral 
practice to investigate online learning communities [14], [15]. He found that students were willing to engage in mutual engagement, joint enterprise, and shared repertoire in their course activities. Yet other research identified difficulties of students in online courses. Cognitive scientists and software engineers suggest that individuals must create mental models to be able to understand and internalize what is happening in this new environment [16]. One study suggested that students had to take time to move through the initial efforts of learning the tools before they began constructing new knowledge [17]. Another study confirms the necessity for learners to have support to learn and act out their roles in these situations [18].

One graduate course demonstrated that even in the case of having independent online lessons, it was useful to add a component that required students to interact with their colleagues in some way [19]. Similarly, it was important to build in practice opportunities for the students to refine their evaluative and analytical skills to be able to successfully use the enormous amount of information on the Internet [20].

\section{METHODOLOGY}

This research was accomplished through two distinct phases, each employing appropriate methods.

\section{A. Phase One}

Phase One was designed to identify the characteristics or dimensions that appeared to play a significant role in the success and satisfaction of students in an online class. Concerns have been raised that potential students of online learning may not fully understand or appreciate the challenges that they face, and further that instructors may not appreciate the challenges that their online students face. The goal was to analyze the topics typically presented to potential students as "advanced organizers" and identify common elements [21]. The material was derived from a variety of sources. To begin, an examination was made of over seventy institutions throughout the world that currently offer post-secondary online learning opportunities. While many more organizations do offer online courses, only those that appeared to have an educational focus, and other components that seem essential for post-secondary education (library facilities, student support personnel, etc.) were considered. The original group was narrowed again, so that only those that offered potential students a chance to investigate their own suitability for this environment, through a substantive needs-assessment, (including advanced organizers, surveys, or other materials) were ultimately considered. This process resulted in a final group of over thirty such institutions.

A document analysis was then completed on those instruments. Standard document analysis techniques were employed to compare the similarities, distinguish the areas of divergence, and identify the various functions of presentation, scoring, feedback, and supporting documentation [22], [23]. After the analysis was completed, a substantial literature review was undertaken, to verify the practical field analysis and to identify areas or characteristics that were missing from that analysis.

\section{B. Phase Two}

Once these dimensions were identified, it was important to verify them through discussion by those with expertise in this area. The information was aggregated and then presented to a sample of online educators. A purposeful sampling was used, which is based on the assumption that one wants to discover, understand, and gain insight, and "therefore one needs to select a sample from which one can learn the most" [24]. Researchers determined particular participants to include because they were known to have 
designed and taught online courses for considerable amounts of time and rate themselves as successful online educators. Participants were further chosen by using a "snowball" model of asking the original experienced educators to nominate others, from around the world. A sample was selected from those who volunteered among the qualified online educators. Ultimately fourteen individuals participated in this study.

A web survey was created in which the dimensions were presented with a detailed explanation. Respondents were asked to answer three questions about each dimension on a scale of 1 to 5 , with 1 indicating the respondents strongly disagreed with the statement, and 5 indicating they strongly agreed. The survey also requested that the respondents describe strategies they have used to support and encourage their online students and to identify any other dimensions that may have been missed. The responses to the Likert questions were analyzed using simple descriptive statistics. The open-ended responses were analyzed using constant comparative methods [25], [26]. The researchers performed this analysis individually and then compared and discussed the findings and their meanings.

\section{RESULTS}

The analysis of the materials derived from the institutions as well as a comprehensive body of literature yielded seven dimensions as critical factors that impact the success of adults who enroll in distance learning courses and degree programs. Although these dimensions are presented separately, in reality they do not function independently. Rather, they are inter-related, as are the pieces of a puzzle, and work together to support or challenge the online learner.

The educators also provided valuable information about the seven dimensions, and several responded that completing the survey gave them time to reflect about their online teaching. In the following section, the seven dimensions are presented with explanations, mean and mode from the survey results, as well as the minimum and maximum scores, to provide some idea of the range of responses on each item. Additionally, experts' comments and strategies are presented with each dimension.

\section{A. Tools}

Access to the tools was an obvious but also undervalued component. The more difficulty the student experienced in getting to the equipment, the easier it was to find reasons to drop the course. The respondents perceived this dimension as significant. Students without regular access to appropriate tools, at home or at their work tend to have more difficulty in succeeding in online learning. Those with reliable access at home were considered to be at a distinct advantage, because they are able to focus on their learning on their own time schedule.

Table 1: Tools

\begin{tabular}{|l|c|c|c|}
\hline Tools - Survey Questions & Mean & Mode & Min/Max \\
\hline $\begin{array}{l}\text { Students without tools at home } \\
\text { are at a disadvantage in this } \\
\text { environment }\end{array}$ & 4.57 & 5 & $4 / 5$ \\
\hline $\begin{array}{l}\text { Access to appropriate tools has } \\
\text { significantly impacted some of } \\
\text { my online students. }\end{array}$ & 4.14 & 4 & $3 / 5$ \\
\hline $\begin{array}{l}\text { Some students have not been } \\
\text { able to join an online class for }\end{array}$ & 4.07 & 4 & $2 / 5$ \\
\hline
\end{tabular}




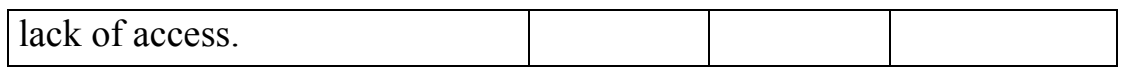

Respondents strongly agreed that this is an important consideration. One stated, "...students, in my experience, tend to get more anxious about the lack of technology and then fail to engage in the coursework to any great depth." Another pointed out, "Their 'minimum' requirements in fact are rising fairly consistently, and as institutions continue to integrate learning/teaching technologies into their courses, this will have growing implications for stratifying access to "the right" tools/information/skills, etc."

\section{B. Technology Experience}

It was not sufficient to have access to the appropriate tools. Students needed to have a level of comfort with using the tools - experience in solving simple problems, checking email, and accomplishing basic tasks (printing or file management, for example). Respondents considered students to have a significant challenge if they had to learn both technology and content at the same time. They reported that they helped students overcome technological discomfort by providing support. For example, one introduced students to the "technological ropes" of the course and allowed them to practice navigating, and another provided support resources, such as $\mathrm{CD}$ and video, that guided students through an online environment so they can become familiar with the environment before they begin the course.

Table 2: Experience

\begin{tabular}{|l|c|c|c|}
\hline $\begin{array}{c}\text { Technology experience - } \\
\text { Survey Questions }\end{array}$ & Mean & Mode & Min/Max \\
\hline $\begin{array}{l}\text { Students who are unfamiliar } \\
\text { with using technology begin an } \\
\text { online class at a disadvantage. }\end{array}$ & 4.15 & 5 & $2 / 5$ \\
\hline $\begin{array}{l}\text { Experience in solving } \\
\text { technological problems has } \\
\text { made students, work easier in } \\
\text { an online class. }\end{array}$ & 3.92 & 4 & $3 / 5$ \\
\hline $\begin{array}{l}\text { Some students have become } \\
\text { frustrated by the technological } \\
\text { challenges to working online. }\end{array}$ & 4.38 & 5 & $3 / 5$ \\
\hline
\end{tabular}

Comments by the respondents extended the understanding of this dimension; one respondent offers the following comment:

It is a challenge for students inexperienced in technology to learn both the technology and content simultaneously. However, a well designed course (using the simplest technology needed to meet the learning objectives) and user-friendly courseware go a long way to ameliorate this difficulty.

\section{Learning Preferences}

Individuals must be able to recognize their own abilities and styles, in order to ask or modify the learning necessary for online environments. This means that a learner who needs to hear classmates discuss difficult theories will need to compensate for this in other ways. It may mean having chat sessions online, or even telephone conference calls. Students can take advantage of visual learning opportunities as well as multiple ways of presenting the content with an online class. However, the educators reported that some 
students have trouble finishing a course because they are concerned about learning alone. They suggested that students work in a group so they feel they are learning in a collaborative and social environment.

Table 3: Learning Preferences

\begin{tabular}{|l|c|c|c|}
\hline $\begin{array}{c}\text { Learning Preferences - } \\
\text { Survey Questions }\end{array}$ & Mean & Mode & Min/Max \\
\hline $\begin{array}{l}\text { Students have said they have } \\
\text { trouble learning from reading. }\end{array}$ & 3.58 & 3 & $2 / 5$ \\
\hline $\begin{array}{l}\text { Some students have requested } \\
\text { adjustments to the materials and } \\
\text { assignments in my online } \\
\text { classes. }\end{array}$ & 3.50 & 4 & $2 / 5$ \\
\hline $\begin{array}{l}\text { I try to provide information in } \\
\text { multiple modalities for my } \\
\text { students. }\end{array}$ & 4.17 & 5 & $2 / 5$ \\
\hline
\end{tabular}

The expert online educators had a lot to say about this particular dimension. One pointed out, "Of course, these things are/will be true even in face-to-face learning environments." Another commented, "Why would we not want to take advantage of the visual learning opportunities with online classes?" And yet, another indicated:

I agree that multiple modalities would help learners who have difficulty reading alone. However, I believe benefits do not outweigh the difficulties such as the increase in download time and students' technical difficulties when adding media files.

\section{Study Habits and Skills}

Learners appear to appreciate the greater control over their learning; yet with that control comes substantial responsibility for completing assignments and being prepared. However, it may be more difficult to stay focused on assignments when sitting alone with a pile of work. People may believe that distance education is quick or easy, however, they quickly learn that many programs challenge the learner with reading and writing assignments. The educators suggested that giving some flexibility was a good way to help students study on their own. For example, they allowed students a block of time in which students may work at their own pace, instead of running a class in a lock step that would have online students essentially behaving like on-campus students. Some of the educators reported that it was occasionally difficult for them to notice how confused students may be from the readings unless they asked frequent questions. The educators suggested that minimum requirements for posting questions and answers on the readings may force students to work harder than in a face-to-face class. Due to the required extra effort, students sometimes find an online class more challenging.

Table 4: Study Habits and Skills

\begin{tabular}{|l|c|c|c|}
\hline $\begin{array}{c}\text { Study Habits and Skills - } \\
\text { Survey Questions }\end{array}$ & Mean & Mode & Min/Max \\
\hline $\begin{array}{l}\text { Students have expressed } \\
\text { difficulties with studying for the } \\
\text { online classes. }\end{array}$ & 3.50 & 4 & $1 / 5$ \\
\hline $\begin{array}{l}\text { Readings seem more difficult } \\
\text { for students within the online }\end{array}$ & 3.0 & 2 & $1 / 5$ \\
\hline
\end{tabular}




\begin{tabular}{|l|l|l|l|}
\hline environment. & & & \\
\hline $\begin{array}{l}\text { I have more difficulty } \\
\text { recognizing students confusion }\end{array}$ & 3.08 & 4 & $1 / 5$ \\
in an online situation. & & & \\
\hline
\end{tabular}

This dimension produced a wide variety of opinions. Comments ranged from "It is difficult to know just how confused students are by the readings and assignments unless they ask questions" to "Quite often students don't tell me they are having difficulties... they just don't do the work and I assume they are having difficulties!" Another added, "It (online) creates a different kind of interaction (not necessarily worse, but different) ... calling for other avenues of perception and response to students' confusion, anxiety, anger, disagreement, discovery, etc." One did express his/her own concern, "I can sense they may be confused, but at what point should intervention take place is an ongoing issue."

\section{E. Goals and Purposes}

Adults have a variety of reasons for seeking educational experiences, and these may include a mandatory upgrade of skills, requirement for additional credits to maintain licensure, need to change careers, or a simple desire to gain knowledge. Explicating this motivation does a great deal to assist in completion of online courses. The educators reported that their successful students usually have high levels of motivation. And, students' purpose for taking the class often tends to impact their initial level of participation.

Table 5: Goals and Purposes

\begin{tabular}{|l|c|c|c|}
\hline \multicolumn{1}{|c|}{$\begin{array}{c}\text { Goals and Purposes - } \\
\text { Survey Questions }\end{array}$} & Mean & Mode & Min/Max \\
\hline $\begin{array}{l}\text { More students have difficulty } \\
\text { staying up with class } \\
\text { assignments in the online } \\
\text { environment. }\end{array}$ & 3.54 & 4 & $1 / 5$ \\
\hline $\begin{array}{l}\text { Students report skepticism about } \\
\text { their taking an online course or } \\
\text { degree. }\end{array}$ & 3.31 & 5 & $1 / 5$ \\
\hline $\begin{array}{l}\text { Students with mandates to take } \\
\text { my classes seem more } \\
\text { motivated. }\end{array}$ & 3.38 & 2 & $2 / 5$ \\
\hline
\end{tabular}

Motivation of students was apparently a topic of much discussion among educators in online environments. One respondent said, "I believe those students who choose to take my classes are more motivated." Another said, "Motivation seems to be a key factor, but not by itself." Yet, one commented, "Our retention rate in our full Bachelor of Teaching degree online is $80 \%+$ over the past four years. These students are selected by an interview process which looks at potential success factors." The point of careful selection seemed clear to many of the respondents. Another said, "My students are selected, so they are usually self motivated. The drop out rate is low."

\section{F. Lifestyle Factors}

It was clear that students had to be aware of the responsibilities that govern their lives, and needed to 
determine if they would have 10-20 hours a week to devote to studying. They may also determine if they have some flexibility in their schedules, or if little room exists for rearrangement. Another significant factor is the amount of support they have from family, friends and co-workers as they pursue their studies. Most students who have dropped an online course mentioned a lack of time to devote to studying. Work related travel and childcare responsibilities are often cited as reasons for non-completion. So, it was deemed important that students have family support. The educators suggested that students need to understand how to balance the complex aspects of their lives with their study programs.

Table 6: Lifestyle Factors

\begin{tabular}{|l|c|c|c|}
\hline $\begin{array}{c}\text { Lifestyle Factors - Survey } \\
\text { Questions }\end{array}$ & Mean & Mode & Min/Max \\
\hline $\begin{array}{l}\text { I am aware that many students } \\
\text { have complex lives that } \\
\text { interfere with their completing } \\
\text { assignments. }\end{array}$ & 4.33 & 5 & $3 / 5$ \\
\hline $\begin{array}{l}\text { Students make personal excuses } \\
\text { about their reasons for not } \\
\text { completing assignments. }\end{array}$ & 3.83 & 4 & $2 / 5$ \\
\hline $\begin{array}{l}\text { Students have reported personal } \\
\text { reasons for dropping my online } \\
\text { courses. }\end{array}$ & 4.25 & 5 & $3 / 5$ \\
\hline
\end{tabular}

Respondents had a lot of agreement on this dimension. One said, "Most students who have dropped my online courses cite a lack of time to complete all the work." One reported on his/her own research and said that "...virtually all students $(91 \%)$ are working at least 10 hours/week outside the home while they are taking an online course, and 55\% are working 30 hours/week or more." One educator provided his/her strategy for this dilemma, "I tell students what I expect of them up front (approximately 150 hours). If that doesn't seem likely, I suggest they take the class in a different semester...." And again, it was pointed out, "These things hold true for both online and face-to-face classes."

\section{G. Personal Traits and Characteristics}

This dimension offers a perspective on fundamental ways in which individuals actually handle their daily activities, and patterns of behavior that go far beyond school related issues. This includes questions about the way one completes daily tasks. Successful online students tend to have a strong commitment to put in their time and effort for the class. The educators reported that the individual differences, such as lack of willingness and self-discipline, are critical factors that impact student success in online classes because there is a higher level of personal responsibility demanded for online students to complete the course.

Table 7: Personal Traits and Characteristics

\begin{tabular}{|l|c|c|c|}
\hline \multicolumn{1}{|c|}{$\begin{array}{c}\text { Personal Traits - Survey } \\
\text { Questions }\end{array}$} & Mean & Mode & Min/Max \\
\hline $\begin{array}{l}\text { Individual and personal } \\
\text { differences are more apparent in } \\
\text { an online class. }\end{array}$ & 3.17 & 3 & $2 / 5$ \\
\hline $\begin{array}{l}\text { Students' individual } \\
\text { characteristics are more }\end{array}$ & 3.00 & 3 & $1 / 5$ \\
\hline
\end{tabular}




\begin{tabular}{|l|l|l|l|}
\hline $\begin{array}{l}\text { problematic in an online } \\
\text { environment. }\end{array}$ & & & \\
\hline $\begin{array}{l}\text { It is more difficult for me to } \\
\text { assist students with their } \\
\text { difficulties electronically. }\end{array}$ & 2.92 & 3 & $1 / 5$ \\
\hline
\end{tabular}

While some of the respondents to this survey felt this dimension was tied closely to study skills, others thought this comprised a separate set of considerations. One said, "The problems that result from individual differences such as lack of organization and self-discipline are more apparent online...the assignments are late!... Overall there is a higher level of personal responsibility demanded of the online student." Again, students have a need to express their concerns to be able to work through any difficulties they are encountering.

In summary, all of the fourteen experts strongly agreed on the importance of students having access to the appropriate tools and having technology experiences prior to taking online classes. They agreed that lifestyle factors, such as completing time demands, play an important role in students' completing online course. Also they showed an agreement on the importance of learning preferences. Most of these experts emphasized the importance of students' goals and purposes that motivated them to take an online course. Study habits and skills, and personal characteristics were not seen as highly important, however, most of the experts commented that self-discipline is one of the most important factors that contributes to success in online learning.

\section{RECOMMENDATIONS}

It is interesting to note that complete agreement did not exist as to the importance of all seven dimensions, and yet, overall, acceptance that these factors are importance was fairly clear. In addition to the strategies given above, these experts summarized their tactics and approaches to online learning. They provided the following suggestions:

- Encourage students to post a short autobiography at the beginning of the course so make them feel they know each other. Ideally, an initial face-to-face meeting or even some informal gatherings during the course establish a sense of community and thus facilitate an active participation.

- Interact with students on a one-to-one and regular basis, especially for those who fall behind. If needed, give support over the phone as well as a site visit.

- Have students work collaboratively on their assignments. Further, encourage students to share their individual work with other students and benefit from feedback.

- Establish minimum levels of participation in a discussion and thus promote ongoing contributions to reciprocal knowledge building.

- Provide readings that are up to date and interesting but at the same time challenging.

- Create some places in an online environment where students can ask each other for help and also create an open forum where students can ask questions directly to a teacher.

- Be flexible in terms of course topics and procedures, and allow these topics to be predominantly generated by students. Even allow students to set up their individual learning goals and negotiate with them.

- Design an online environment using a technologically minimalist approach, reducing technological requirements and potential difficulties. 
In summary, the educators were incorporating active, collaborative, and constructivist learning strategies for their online classes rather than taking a traditional lecture model. They credited their success to their individual willingness to respond and their flexible style of working with individuals and groups of learners. They also agreed that the more potential learners knew before they began taking an online course, the better their experience and outcomes would be.

\section{CONCLUSION}

Currently many public, private, and for-profit institutions are rushing toward the development and promotion of electronic educational environments. Their motivations are quite varied, but, overall, student success must be an outcome worthy of attention. This research presents seven dimensions of student success in online environments and also gathers various perspectives on these dimensions from educators who are well experienced in teaching in these environments. The experienced educators provide valuable insight into their strategies for ensuring student success and methods of accommodation for those students new to the online learning world. Most importantly, there is agreement that potential students have a need to understand the qualities and characteristics of online learning. It is essential that educators share their experiences as a body of research develops, new theories about this phenomenon evolve, and significant numbers of learners look to institutions for appropriate learning opportunities.

\section{REFERENCES}

1. Radford, A. The future of multimedia in education, First Monday, Vol. 2, No. 11, Available online at http://131.193.231/issues/issue2 11/radford/index.html, 1997.

2. Gibbs, W. J. Implementing online learning environments, Journal of Computers in Higher Education, Vol. 10, No. 1, pp. 16-37, 1998.

3. Palloff, R. M., and Pratt, K. Building learning communities in cyberspace: Effective strategies for the online classroom, San Francisco: Jossey-Bass Publishers, 1999.

4. Schrum, L. On-line education: A study of emerging pedagogy, In Cahoon, B. (Ed.), Adult Learning and the Internet, Vol. 78, Jossey-Bass Publishers, San Francisco, pp. 53-61, 1998.

5. Gerencher, K.. MBA programs go online, InfoWorld, Vol. 20, pp. 71-72, 1998.

6. Mangan, K. S. Top business schools seek to ride a bull market in on-line MBA's, The Chronicle of Higher Education, Vol. 45, No. 19, pp. A27-A28, 1999.

7. Candiotti, A., and Clarke, N. Combining universal access with faculty development and academic facilities, Communications of the ACM, Vol. 41, No. 1, pp. 36-41, 1998.

8. Schrum, L., and Berge, Z. L. Creating student interaction within the educational experience: A challenge for online teachers, Canadian Journal of Educational Communication Vol. 26, No. 3, pp. 133-144, 1998.

9. Schrum, L., \& Benson, A. Online professional education: A case study of an MBA program through its transition to an online model, Journal of Asynchronous Learning Environments Vol. 4, No. 1, Available online at http://www.aln.org/alnweb/journal/Vol4_issue1/schrum.htm 2000.

10. Kember, D. Open learning courses for adults: A model of student progress, Englewood Cliffs, N.J.: Educational Technology Publications, 1995.

11. Schrum, L. Online teaching and learning: Essential conditions for success!, In Lau, L. (Ed.), Online teaching and learning, Idea Group Publishing, Hershey, PA, pp. 91-106, 2000

12. Wiesenberg, F., and Hutton, S. Teaching a graduate program using computer-mediated conferencing software, Journal of Distance Education, Vol. 11, No. 1, pp. 83-100, 1996. 
13. Broad, M. The dynamics of quality assurance in online distance education, Electronic Journal of Instructional Science and Technology, Vol. 3, No. 1, Available online at http://www.usq.edu.au/electpub/e-jist/voleno1/index.htm 1999.

14. Rogers, J. Communities of practice: A framework for fostering coherence in virtual learning communities, Educational Technology \& Society, Vol. 3, No. 3, Available online at http://grouper.ieee.org/groups/ifets/periodical/vol 3 2000/e01.html, 2000.

15. Wenger, E. Communities of practice: Learning, meaning, and identity, Cambridge: University Press, 1998.

16. Brandt, D. S. Constructivism: Teaching for understanding of the Internet, Communication of the ACM, Vol. 40, No. 10, pp. 112-117, 1997.

17. Yakimovicz, A. D., and Murphy, K. L. Constructivism and collaboration on the Internet: Case study of a graduate class experience, Computers and Education, Vol. 24, No. 3, pp. 203-209, 1995.

18. Olson, M. H., and Bly, S. A. The Portland experience: A report on a distributed research group', In Greenberg, S. (Ed.), Computer supported cooperative work and groupware, Academic Press Limited, San Diego, pp. 81-98, 1991.

19. Dehler, C., and Poirras-Hernandez, L. H. Using computer mediated communication (CMC) to promote experiential learning in graduate studies, Educational Technology, Vol. 38, No. 5, pp. 52$55,1998$.

20. King, K. P. Course development on the world wide web, In Cahoon, B. (Ed.), Adult Learning and the Internet Vol. 78, Jossey-Bass Publishers, San Francisco, pp. 25-32, 1998.

21. Schrum, L. Students and online learning: Dimensions that promote success, (Unpublished report). Atlanta, GA: Georgia Learning Online for Business and Education, 1999.

22. Merriam, S. B. Qualitative research and case study applications in education, (2nd ed.). San Francisco: Jossey-Bass Publishers, 1998.

23. Weber, R. P. Basic content analysis, (2nd ed.), Newbury Park, CA: Sage, 1990.

24. Merriam, S. B. Case study research in education: A qualitative approach, San Francisco: JosseyBass Publishers, 1988.

25. Miles, M. B., and Huberman, A. M. Qualitative data analysis, Newbury Park, CA: Sage Publications, 1984.

26. Lincoln, Y. S., and Guba, E. G. Naturalistic inquiry, Newbury Park, CA: SAGE Publications, 1985.

\section{ABOUT THE AUTHORS}

Lynn Schrum, Ph.D., is professor of education at the University of Georgia and president of the International Society for Technology in Education.

Sunjoo Hong is a graduate student in the University of Georgia Department of Instructional Technology. 